\title{
Characterization of Stormwater at Selected South Carolina Department of Transportation Maintenance Yards and Section Shed Facilities in Ballentine, Conway, and North Charleston, South Carolina, 2010-12
}

\section{Introduction}

Increased impervious surfaces (driveways, parking lots, and buildings) and human activities (residential, industrial, and commercial) have been linked to substantial changes in both the quality and quantity of stormwater on a watershed scale (Brabec and others, 2002; Pitt and Maestre, 2005). Small-scale storage and equipment repair facilities increase impervious surfaces that prevent infiltration of stormwater, and these facilities accommodate activities that can introduce trace metals, organic compounds, and other contaminants to the facility's grounds. Thus, these small facilities may contribute pollutants to the environment during storm events (U.S. Environmental Protection Agency, 1992).

The South Carolina Department of Transportation (SCDOT) operates section shed and maintenance yard facilities throughout the State. Prior to this investigation, the SCDOT had no data to define the quality of stormwater leaving these facilities. To provide these data, the U.S. Geological Survey (USGS), in cooperation with the SCDOT, conducted an investigation to identify and quantify constituents that are transported in stormwater from two maintenance yards and a section shed in three different areas of South Carolina (fig. 1). The two maintenance yards, in North Charleston and Conway, S.C., were selected because they represent facilities where equipment and road maintenance materials are stored and complete equipment repair operations are conducted. The section shed, in Ballentine, S.C., was selected because it is a facility that stores equipment and road maintenance material. Characterization of the constituents that were transported in stormwater from these representative SCDOT maintenance facilities may be used by the SCDOT in the development of stormwater management plans for similar section shed and maintenance yard facilities throughout the State to improve stormwater quality.

\section{Description of the Study Area}

The Ballentine section shed has a drainage area of 12,133 square meters $\left(\mathrm{m}^{2}\right)\left(0.0047\right.$ square mile $\left.\left(\mathrm{mi}^{2}\right)\right)$, and 79 percent of the area is composed of impervious surface (table 1; fig. 2). Stormwater drainage from the study area is surficial sheet flow that is diverted by a curb-and-gutter system to a retention basin or pond that is dry except during storms. Stormwater enters the retention pond through drainage pipes. Stormwater accumulates in the retention pond until there is enough water depth and flow to exit the retention pond through the main outfall that then directs the stormwater off the facility to a roadside ditch.
The Conway maintenance yard has a drainage area of 41,207 $\mathrm{m}^{2}$ $\left(0.01590 \mathrm{mi}^{2}\right)$ with a curb-and-gutter system to capture stormwater as it runs off the facility (fig. 3). The total impervious surface of the facility is 70 percent. Water drainage from the study area is surficial sheet flow that discharges to two outfalls within the study site. The Conway1 outfall, near the fuel island at the southern end of the property, was modified by installing a 6-inch polyvinyl chloride (PVC) pipe to sample the stormwater discharge (fig. 3). This outfall has a drainage area of $1,200 \mathrm{~m}^{2}\left(0.00046 \mathrm{mi}^{2}\right)$, and the area is entirely (100 percent) composed of impervious surface (table 1). The Conway 2 outfall is at the beginning of a grass-lined ditch that drains the northern part of the site (fig. 3). Stormwater was captured and directed to this outfall by a curb-and-gutter system. The drainage area is $9,912 \mathrm{~m}^{2}\left(0.0038 \mathrm{mi}^{2}\right)$ with 100 percent impervious surface (table 1).

Stormwater discharges from the North Charleston maintenance yard to Turkey Creek, a perennial stream, through a combination of pipes, ditches, and overland flow. In order to sample stormwater from all areas of the yard, samples were collected from the main channel of Turkey Creek at the upstream (North Charleston1) and downstream (North Charleston2) limits of the North Charleston maintenance yard facility (fig. 4). Drainage area of the maintenance yard is $85,999 \mathrm{~m}^{2}$ $\left(0.033 \mathrm{mi}^{2}\right)$, and the total impervious surface is 62 percent (table 1). Stormwater constituents in the water samples at the upstream site (North Charleston1) represent stormwater contributions from the headwater drainage area above the North Charleston property.

\section{Data Collection and Analysis}

From January 2010 through January 2012, the USGS operated data-collection stations at the five study sites (table 1). The datacollection effort included monitoring the quantity of rainfall and the collection of stormwater-quality samples. Established guidelines and protocols were used to ensure the data were of the highest quality. As many as nine storm samples were collected at five locations that received stormwater discharge from the Ballentine (one outfall, nine samples), North Charleston (two locations on Turkey Creek, eight samples each), and Conway (two outfalls, Conwayl eight samples, Conway2 seven samples) facilities. The samples were analyzed for nutrients, fecal indicator bacteria, total and dissolved concentrations of six trace metals (cadmium, copper, chromium, lead, nickel, and zinc), and suspended sediment. Stormwater samples also were analyzed for synthetic and semivolatile organic compounds, including 10 herbicides, 18 organochlorine pesticides, 7 Aroclor congeners, 44 volatile organic compounds, and 16 polycyclic aromatic hydrocarbons. 


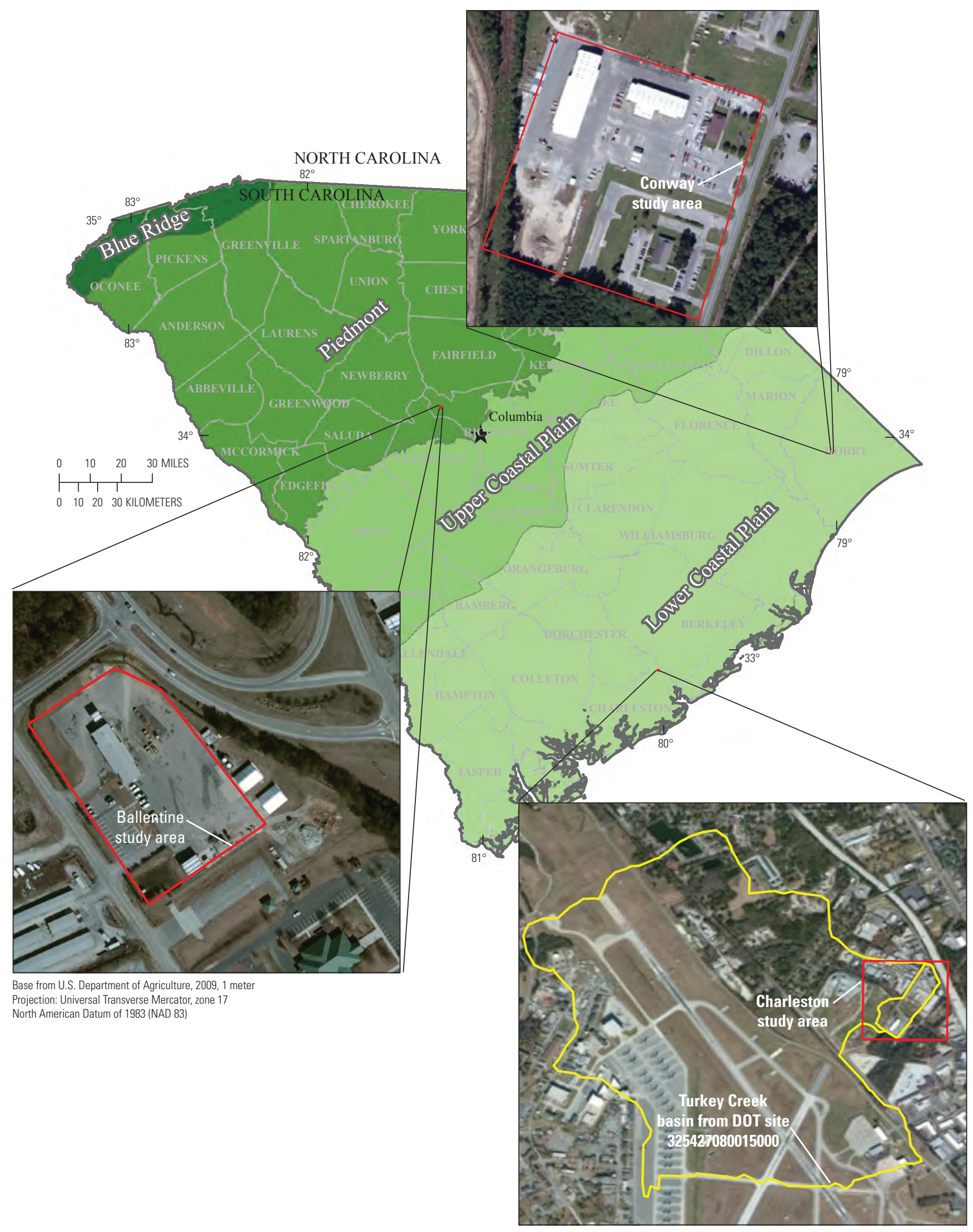

Figure 1. Location of South Carolina Department of Transportation (DOT) Ballentine section shed, Conway and North Charleston maintenance yards, Turkey Creek Basin in South Carolina. 
Table 1. Description of South Carolina Department of Transportation maintenance yard and section shed sites in North Charleston, Conway, and Ballentine, South Carolina.

[NWIS, National Water Information System database of the U.S. Geological Survey; ID, identification; $\mathrm{m}^{2}$, square meters; mi², square miles; $\mathrm{ft}^{3} / \mathrm{s}$, cubic feet per second; SCDOT, South Carolina Department of Transportation; S.C., South Carolina; NS, not sampled; ND, not determined]

\begin{tabular}{|c|c|c|c|c|c|c|c|c|}
\hline \multirow{2}{*}{$\begin{array}{l}\text { NWIS station } \\
\text { identification } \\
\text { number }\end{array}$} & \multirow{2}{*}{ NWIS station name } & \multirow{2}{*}{ Site ID } & \multicolumn{2}{|c|}{ Drainage area } & \multirow{2}{*}{$\begin{array}{l}\text { Impervious } \\
\text { surface } \\
\text { (percent) }\end{array}$} & \multirow{2}{*}{$\begin{array}{c}\text { Number of } \\
\text { samples } \\
\text { collected }\end{array}$} & \multirow{2}{*}{$\begin{array}{c}\text { Average } \\
\text { event-mean } \\
\text { stormwater } \\
\text { discharge } \\
\left(\mathrm{ft}^{3} / \mathrm{s}\right) \\
\end{array}$} & \multirow{2}{*}{$\begin{array}{c}\text { Average event } \\
\text { mean unit-area } \\
\text { stormwater } \\
\text { discharge } \\
\left(\left[\mathrm{ft}^{3} / \mathrm{s}\right] / \mathrm{mi}^{2}\right)\end{array}$} \\
\hline & & & $\mathbf{m}^{2}$ & $\mathrm{mi}^{2}$ & & & & \\
\hline 340801081142000 & $\begin{array}{l}\text { SCDOT maintenance yard } \\
\text { outfall near Ballentine, } \\
\text { S.C. }\end{array}$ & Ballentine & 12,133 & 0.005 & 79 & 9 & 0.33 & 70.2 \\
\hline 335444079024500 & $\begin{array}{l}\text { Outfall } 1 \text { from SCDOT } \\
\text { maintenance yard, } \\
\text { Conway, S.C. }\end{array}$ & Conway1 & 1,200 & 0.000 & 100 & 9 & 0.16 & 348 \\
\hline \multirow[t]{2}{*}{335448079024500} & $\begin{array}{l}\text { Outfall } 2 \text { from SCDOT } \\
\text { maintenance yard, } \\
\text { Conway, S.C. }\end{array}$ & Conway2 & 9,912 & 0.004 & 100 & 8 & 0.67 & 176 \\
\hline & ND & $\begin{array}{c}\text { Conway mainte- } \\
\text { nance yard }\end{array}$ & 41,207 & 0.016 & 70 & NS & NS & NS \\
\hline 021720646 & $\begin{array}{l}\text { Turkey Creek at SCDOT } \\
\text { maintenance yard, North } \\
\text { Charleston, S.C. }\end{array}$ & North Charleston 1 & $3,909,680$ & 1.510 & ND & 8 & 3.06 & 2.0 \\
\hline \multirow[t]{2}{*}{325427080014600} & $\begin{array}{l}\text { Turkey Creek below SCDOT } \\
\text { maintenance yard, North } \\
\text { Charleston, S.C. }\end{array}$ & North Charleston2 & $3,995,679$ & 1.543 & ND & 8 & 5.39 & 3.5 \\
\hline & ND & $\begin{array}{l}\text { North Charleston } \\
\text { maintenance } \\
\text { yard }\end{array}$ & 85,999 & 0.033 & 62 & NS & 2.35 & 71.2 \\
\hline
\end{tabular}

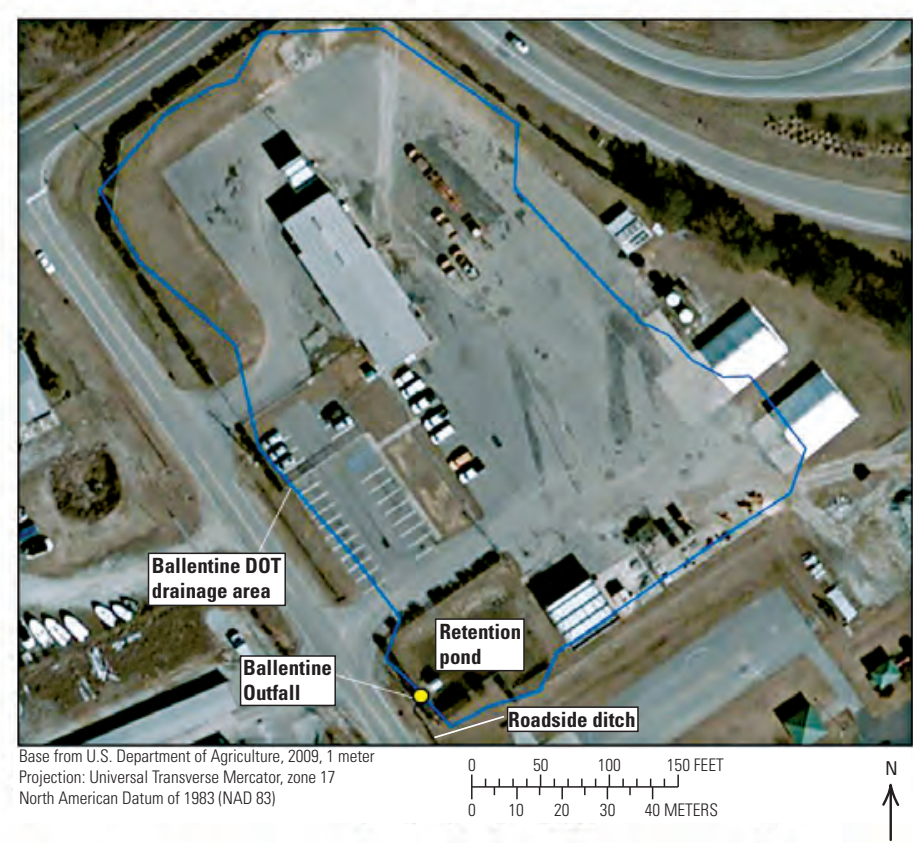

Figure 2. Aerial photograph of drainage area delineation of the South Carolina Department of Transportation (DOT) section shed and outfalls, Ballentine, South Carolina.

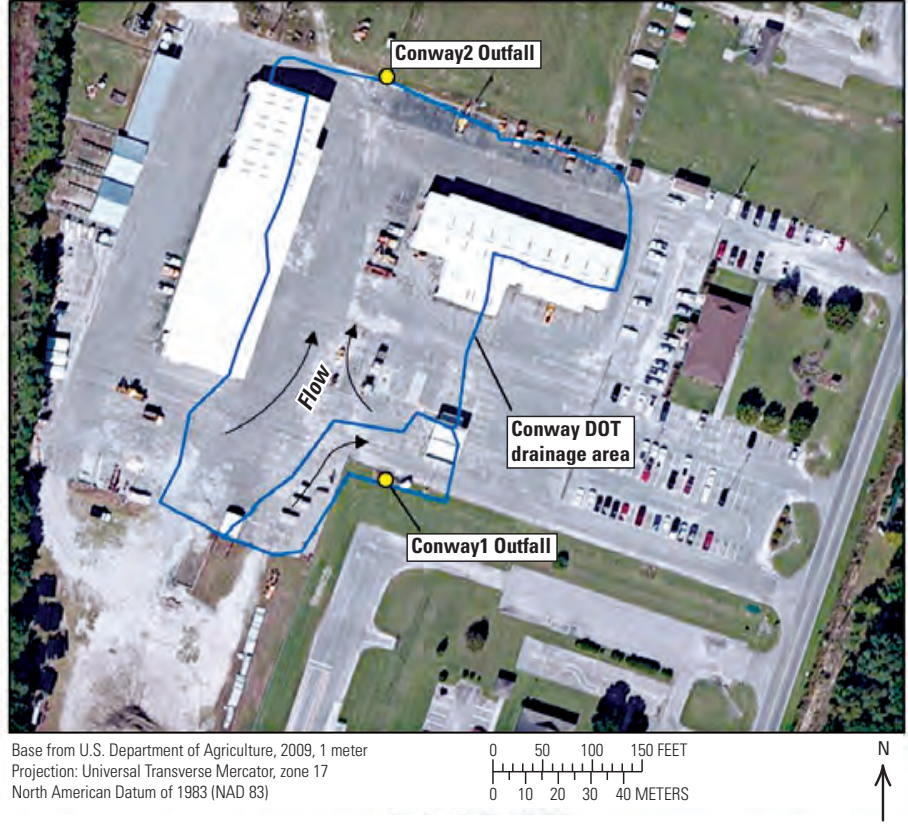

Figure 3. Aerial photograph of drainage area delineation of the South Carolina Department of Transportation (DOT) maintenance yard and outfalls, Conway, South Carolina. 


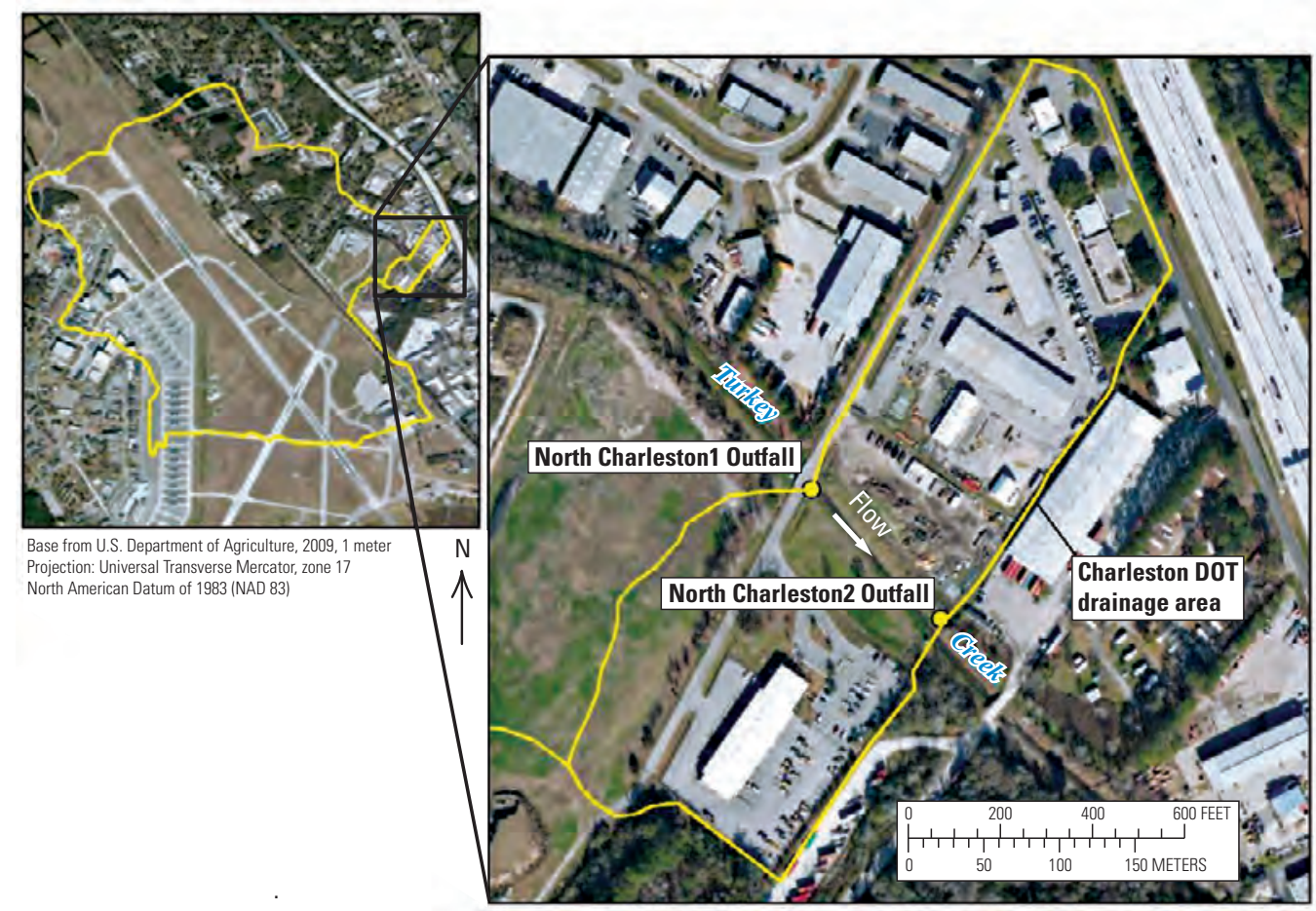

Figure 4. Aerial photograph of drainage area delineation of the South Carolina Department of Transportation (DOT) maintenance yard and outfalls, North Charleston, South Carolina.

\section{Summary and Conclusions}

The storms sampled during this study had a wide range of rainfall amounts, durations, and intensities at each of the facilities and, therefore, were considered to be reasonably representative of the potential for contaminant transport. At all facilities, stormwater discharge was significantly correlated to rainfall amount and intensity. Eventmean unit-area stormwater discharge increased with increasing impervious surface at the Conway and North Charleston maintenance yards. The Ballentine facility, with 79 percent impervious surface, had a mean unit-area discharge similar to that of the North Charleston maintenance yard (62 percent impervious surface). That similarity may be attributed, in part, to the effects of the retention pond on the stormwater runoff at the Ballentine facility and to the greater rainfall intensities and amounts at the North Charleston facility.

Stormwater often transports large quantities of sediment and sediment-bound contaminants, including nutrients and fecal indicator bacteria. Median event-mean concentrations of suspended sediment in stormwater at these facilities ranged from 54 milligrams per liter (mg/L) in Turkey Creek at North Charleston 2 to $147 \mathrm{mg} / \mathrm{L}$ in stormwater discharging from the Ballentine retention pond outfall. In general, event-mean concentrations of total nitrogen consisted mainly of total Kjeldahl nitrogen (organic nitrogen plus ammonia) rather than nitrate plus nitrite in stormwater, and the median event-mean concentrations of total nitrogen ranged from $1.59 \mathrm{mg} / \mathrm{L}$ at the Conwayl pipe outfall to $2.00 \mathrm{mg} / \mathrm{L}$ at the Ballentine retention pond outfall. Median event-mean concentrations of total phosphorus in stormwater ranged from $0.15 \mathrm{mg} / \mathrm{L}$ at the Conwayl outfall to $0.42 \mathrm{mg} / \mathrm{L}$ in Turkey Creek at North Charleston1.

Escherichia coli (E. coli) and enterococcus concentrations often varied by 3 to 4 orders of magnitude in grab samples collected during the "first flush" of stormwater discharging to the sampled outfalls of Turkey Creek. Additionally, enterococcus concentrations consistently were greater than the corresponding $E$. coli concentrations in stormwater samples. Specifically, median "first-flush" E. coli concentrations ranged from 30 colonies per 100 milliliters (col/100 mL) at the Conway1 outfall to $4,359 \mathrm{col} / 100 \mathrm{~mL}$ in Turkey Creek at North Charleston2, whereas enterococcus concentrations ranged from $512 \mathrm{col} / 100 \mathrm{~mL}$ at the Conway1 outfall to 6,329 col/100 mL in Turkey Creek at North Charleston2. Compared to the proposed South Carolina Department of Health and Environmental Control primary and secondary body contact criterion of $349 \mathrm{col} / 100 \mathrm{~mL}$ (South Carolina Department of Health and
Environmental Control, 2012), stormwater samples had $E$. coli concentrations that were greater than the criterion in four of the nine storms at the Ballentine retention pond outfall, one of the eight storms at the Conwayl pipe outfall, five of the seven storms at the Conway2 grass-lined ditch outfall, two of the eight storms at North Charleston 1 on Turkey Creek, and eight of the eight storms at North Charleston2 on Turkey Creek.

Of the six trace metals measured in stormwater, only copper and zinc had event-mean concentrations greater than the hardness-dependent South Carolina Department of Health and Environmental Control aquatic life criteria maximum concentrations (South Carolina Department of Health and Environmental Control, 2012). Measured dissolved copper event-mean concentrations in stormwater were greater than the criterion in five of the samples at the Ballentine facility, one of the samples at Conway1, two of the samples at Conway2, and one of the samples at North Charleston2. Measured dissolved zinc event-mean concentrations in stormwater were greater than the criterion in three of the samples at the Ballentine facility, one of the samples at Conway1, two of the samples at Conway2, and zero of the samples at North Charleston2. At North Charleston 1 upstream from the North Charleston maintenance yard, the measured dissolved trace-metal concentrations were all less than the criterion maximum concentrations.

Among the three facilities, Conway 1 outfall had the greatest range in event-mean yields in stormwater for total phosphorus, total nitrogen, total suspended solids, and suspended sediment, and both Conway outfalls tended to have median event-mean yields greater than those of the Ballentine and North Charleston yard facilities. "Firstflush" yields of $E$. coli in stormwater were not statistically different among the three facilities.

Median event-mean yields of suspended sediment, total nitrogen, total phosphorus, total copper, and total zinc in stormwater demonstrated a strong linear relation to impervious surface at the three facilities. However, median "first-flush" fecal indicator bacterial yields did not have a linear relation to impervious surface.

\section{References}

Brabec, E., Schulte, S., and Richards, P.L., 2002, Impervious surfaces and water quality - A review of current literature and its implications for watershed planning: Journal of Planning Literature, v. 16, no. 4, p. 499-514, accessed March 25, 2013, at http://dandelion-patch.mit.edu/afs/athena.mit. edu/dept/cron/project/urban-sustainability/Stormwater_Sarah\%20Madden/ References/Brabec_etal2002.pdf.

Pitt, R.E., and Maestre, A., 2005, Stormwater quality as described in the National Stormwater Quality database (NSQD): Proceedings of the 10th International Conference on Urban Drainage, Copenhagen, Denmark, August 21-25, 2005, p. 1-8.

South Carolina Department of Health and Environmental Control, 2012, Water classifications and standards: South Carolina Department of Health and Environmental Control, Code of Regulations, State Register, Regulation 61-68, accessed January 31, 2013, at http://www.scdhec.gov/environment/ water/regs/r61-68.pdf.

U.S. Environmental Protection Agency, 1992, NPDES storm water sampling guidance document: U.S. Environmental Protection Agency, Office of Water, EPA 833-B-91-001.

By Celeste A. Journey (cajourney@usgs.gov) and Kevin J. Conlon (kjconlon@usgs.gov), South Carolina Water Sceince Center 